\title{
Prehipertensi sebagai Prediktor Perlemakan Hati Non Alkoholik pada Obesitas Sentral Usia Dewasa Muda
}

\author{
${ }^{1}$ Fadil Dewantara, ${ }^{2}$ Frans E. N. Wantania
}

\author{
${ }^{1}$ Program Studi Pendidikan Dokter Fakultas Kedokteran Universitas Sam Ratulangi Manado \\ ${ }^{2}$ Bagian Ilmu Penyakit Dalam Fakultas Kedokteran Universitas Sam Ratulangi Manado \\ Email: fadildewantara60@gmail.com; wantaniaerwinfrans@ unsrat.ac.id
}

\begin{abstract}
Fatty liver is one of the early complications of obesity in adolescents. This state may develop to steatohepatitis and liver cirrhosis in the future. Recent studies show the association between prehypertension and left ventricular hypertrophy in adolescents. This study was aimed to determine prehypertension as a risk factor of non alcoholic fatty liver disease (NAFLD) in central obesity. This study was conducted at the Department of Internal Medicine Prof. Dr. R. D. Kandou Hospital, Manado. There were 50 medical students (undergraduate and postgraduate) aged 20-40 years of either sex included in this study. Blood pressure, body weight, and waist circumferences were measured. According to JNC-7 guidelines, a systolic blood pressure of 120 to $139 \mathrm{mmHg}$ and/or diastolic blood pressure of 80 to $89 \mathrm{mmHg}$ is considered as prehypertension. The results showed that of 25 subjects with NAFLD, there were 18 subjects with prehypertension, while only 9 subjects with prehypertension in non NAFLD group. There was a significant association between prehypertension and the incidence of NAFLD in central obesity $(\mathrm{OR}=4,571$; CI 95\%=1,38315,109; $P=0,011$ ). Conclusion: Prehypertension is a risk factor of NAFLD in young adults with central obesity. We may use prehypertension to predict the occurence of NAFLD in young adults with central obesity.
\end{abstract}

Keywords: prehypertension, fatty liver, central obesity

\begin{abstract}
Abstrak: Perlemakan hati merupakan salah satu komplikasi dini dari obesitas yang bisa terjadi sejak usia muda dan dapat berlanjut menjadi sirosis bila tidak segera ditangani. Penelitian terdahulu telah melaporkan adanya hubungan antara prehipertensi dengan pembesaran jantung kiri pada laki-laki usia dewasa muda dengan obesitas sentral. Penelitian ini bertujuan untuk membuktikan apakah prehipertensi dapat dijadikan prediktor penyakit perlemakan hati non alkoholik (PPHNA) pada dewasa muda dengan obesitas sentral. Jenis penelitian ialah analitik dengan studi kohort retrospektif (case-control study). Penelitian dilakukan di RSUP Prof. Dr. R. D. Kandou Manado. Subyek penelitian ialah mahasiswa Fakultas Kedokteran Universitas Sam Ratulangi (FK Unsrat) dan PPDS Ilmu Penyakit Dalam FK UNSRAT dengan obesitas sentral (lingkar perut $>90 \mathrm{~cm}$ ). Diagnosis PPHNA ditegakkan oleh dua radiolog yang berbeda. Diagnosis prehipertensi ditegakkan bila tekanan darah sistolik $\geq 130 \mathrm{mmHg}$ tetapi $<140 \mathrm{mmHg}$, dan atau tekanan darah diastolik $>85 \mathrm{mmHg}$ tetapi $<90$ mmHg. Dari 50 subyek penelitian ini, 25 di antaranya dengan PPHNA dan 25 non PPHNA sebagai kelompok kontrol. Pada kelompok PPHNA terdapat 18 subyek dengan prehipertensi dan 7 subyek normotensi. Pada kelompok non PPHNA terdapat 9 subyek dengan prehipertensi dan sisanya dengan normotensi. Uji chi square terhadap hubungan antara prehipertensi dengan kemungkinan terjadi PPHNA pada obesitas sentral mendapatkan adanya hubungan bermakna antara prehipertensi dengan kejadian PPHNA pada subyek (OR=4,571; CI 95\%=1,383-15,109; $P=0,011)$. Simpulan: Prehipertensi merupakan salah satu faktor risiko terjadinya NAFLD pada obesitas sentral usia dewasa muda. Peningkatan ringan tekanan darah dapat dijadikan prediktor terjadinya PPHNA pada obesitas sentral.
\end{abstract}

Kata kunci: prehipertensi, perlemakan hati, obesitas sentral 
Perlemakan hati merupakan salah satu komplikasi dini dari obesitas yang bisa terjadi sejak usia muda dan dapat berlanjut menjadi sirosis bila tidak segera ditangani. Itulah sebabnya penting untuk mendeteksi keadaan ini sedini mungkin. Kejadian prehipertensi di Indonesia masih sedikit diketahui, terutama pada usia dewasa muda, padahal penelitian menunjukkan bahwa lebih dari $50 \%$ pasien prehipertensi memiliki satu atau lebih faktor risiko penyakit kardiovaskular dibandingkan dengan mereka yang normotensi. ${ }^{1}$

Laporan dari JNC-7 telah merekomendasikan secara resmi istilah prehipertensi ini. ${ }^{2}$ Penelitian-penelitian terdahulu menunjukkan bahwa individu dengan tekanan darah lebih dari 120/80 $\mathrm{mmHg}$ namun kurang dari 140/90 mmHg, memiliki kecenderungan untuk menjadi hipertensi, terkena penyakit kardiovaskular, dan kematian pada usia dini akibat penyebab kardiovaskular. ${ }^{3}$

Mahasiswa kedokteran memiliki kesibukan studi terutama pada masa kepaniteraan klinik di Rumah Sakit sehingga waktu berolahraga terbatas, yang berdampak terhadap kenaikan berat badan. Obesitas, terutama obesitas sentral merupakan faktor risiko terjadinya perlemakan hati, apalagi bila disertai dengan peningkatan tekanan darah. ${ }^{4}$ Pada penelitian terdahulu telah dilaporkan adanya hubungan antara prehipertensi dengan pembesaran jantung kiri pada pria obesitas sentral usia dewasa muda. ${ }^{5}$ Penelitian ini bertujuan untuk membuktikan apakah prehipertensi dapat dijadikan prediktor perlemakan hati non alkoholik (PPHNA) pada obesitas sentral usia dewasa muda.

\section{METODE PENELITIAN}

Penelitian ini merupakan penelitian analitik dengan studi kohort retrospektif (case-control study). Penelitian dilakukan di RSUP Prof. Dr. R.D. Kandou Manado sejak bulan Februari sampai Juni 2019. Subyek penelitian ialah 50 mahasiswa FK UNSRAT dan PPDS Ilmu Penyakit Dalam FK Unsrat dengan obesitas sentral (lingkar perut $>90 \mathrm{~cm}$ ) dan berusia 20-40 tahun.
Dilakukan pemeriksaan tekanan darah, berat badan, dan lingkar perut.

Diagnosis NAFLD ditegakkan oleh dua radiolog yang berbeda. Dikatakan perlemakan hati bila terdapat peningkatan ekogenitas dari hati dibandingkan korteks ginjal, serta diafragma dan vena porta tidak tampak jelas. ${ }^{6}$

Diagnosis prehipertensi ditegakkan berdasarkan definisi dari JNC 7 yaitu bila tekanan darah sistolik (TDS) $\geq 130 \mathrm{mmHg}$ tetapi $<140 \mathrm{mmHg}$, dan atau tekanan darah diastolic (TDD) $>85 \mathrm{mmHg}$ tetapi $<90$ mmHg. ${ }^{1}$ Pemeriksaan tekanan darah menggunakan sphygmomanometer Riester dan dilakukan dua kali saat subyek duduk rileks dan telah beristirahat minimal 10 menit tanpa aktivitas fisik.

Kriteria eksklusi meliputi anemia, hipotensi, dan infeksi akut. Analisis statistik menggunakan uji chi square untuk melihat hubungan antara prehipertensi dengan kemungkinan terjadinya perlemakan hati non alkoholik pada obesitas sentral dengan menggunakan program SPSS.

\section{HASIL PENELITIAN}

Pada penelitian ini didapatkan 50 subyek dengan obesitas sentral yang terdiri dari 25 subyek dengan PPHNA dan 25 subyek non PPHNA sebagai kelompok kontrol. Tabel 1 memperlihatkan usia subyek berkisar 20-40 tahun dimana prehipertensi lebih banyak ditemukan pada kelompok PPHNA dibandingkan dengan kelompok non PPHNA. Pada kelompok PPHNA didapatkan 18 subyek dengan prehipertensi, sedangkan pada kelompok non PPHNA terdapat 9 orang dengan prehipertensi. Gambar 1 menunjukkan bahwa lebih dari setengah subyek penelitian (PPHNA dan Non PPHNA) mengalami prehipertensi (54\%).

Tabel 2 menunjukkan bahwa terdapat hubungan bermakna antara prehipertensi dengan kejadian PPHNA pada mahasiswa FK Universitas Sam Ratulangi Manado $(P=0,011)$. Pada kelompok PPHNA didapatkan lebih banyak subyek dengan prehipertensi (18 orang) dibandingkan dengan yang normotensi (7 orang). 
Tabel 1. Karakteristik subyek penelitian

\begin{tabular}{lcccccc}
\hline & N & \multicolumn{2}{c}{ PPHNA (+) } & N & \multicolumn{2}{c}{ PPHNA (-) } \\
& & Min-maks & Mean & & Min-maks & Mean \\
\hline Usia (tahun) & 25 & $25-39$ & 30,04 & 25 & $21-40$ & 30,40 \\
TDS (mmHg) & 25 & $110-130$ & 124,40 & 25 & $110-130$ & 120,80 \\
TDD (mmHg) & 25 & $70-85$ & 81,00 & 25 & $70-85$ & 77,80 \\
\hline
\end{tabular}

Tabel 2. Hubungan antara prehipertensi dengan NAFLD

\begin{tabular}{lccccc}
\hline & PPHNA (+) & PPHNA (-) & Odds Ratio & CI 95\% & P value \\
\hline Prehipertensi & 18 & 9 & 4,571 & $1,383-$ & $P=0,011$ \\
Normotensi & 7 & 16 & & 15,109 & \\
T o t a l & 25 & 25 & & & \\
\hline
\end{tabular}

Sebaliknya, pada kelompok non PPHNA ditemukan lebih banyak subyek dengan normotensi (16 orang), dibandingkan dengan subyek yang prehipertensi (9 orang).

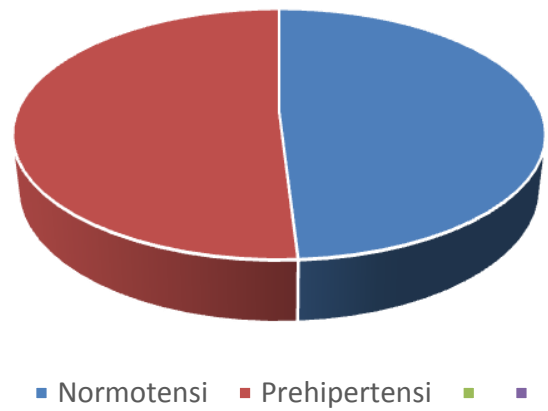

Gambar 1. Proporsi Prehipertensi pada Subyek Penelitian

\section{BAHASAN}

Kejadian prehipertensi di Indonesia masih sedikit diketahui, terutama pada usia dewasa muda. Lewingston et $\mathrm{al}^{1}$ menyatakan bahwa lebih dari $50 \%$ pasien prehipertensi memiliki satu atau lebih faktor risiko penyakit kardiovaskular bila dibadingkan dengan yang normotensi.

Mahasiswa kedokteran memiliki kesibukan studi terutama pada masa kepaniteraan klinik di Rumah Sakit sehingga waktu berolahraga terbatas. Tuntutan dalam pendidikan dan pelayanan sekaligus di Rumah Sakit dapat berdampak terhadap pola aktivitas sehari-hari, seperti pola makan makanan cepat saji yang menawarkan kepraktisan. Kombinasi antara prehipertensi dengan faktor risiko lainnya akan meningkatkan risiko terkenanya kejadian kardiovaskular di masa mendatang bagi individu dengan prehipertensi. ${ }^{7}$

Berdasarkan skor risiko Framingham, individu dengan prehipertensi berisiko dua kali lipat mengalami kejadian penyakit kardiovaskular di masa mendatang dibandingkan dengan mereka yang tekanan darahnya normal. ${ }^{7,8}$ Keadaan prehipertensi telah dibuktikan berhubungan dengan kerusakan organ target seperti arteriosclerosis dini, kalsifikasi arteri koroner, remodeling pembuluh darah, serta pembesaran jantung kiri. ${ }^{9,10}$

Hasil uji statistik pada penelitian ini menunjukkan bahwa prehipertensi berhubungan secara bermakna dengan kejadian PPHNA pada subyek $(\mathrm{OR}=4,571 ; 95 \%$ $\mathrm{CI}=1,383-15,109 ; P=0,011)$. Aneni et $\mathrm{al}^{11}$ juga melaporkan bahwa terdapat hubungan antara prehipertensi dan hipertensi dengan kejadian PPHNA pada laki-laki dan perempuan usia pertengahan di Brasil.

Pada penelitian ini, didapatkan Odds Ratio 4,571 yang berarti bahwa subyek dengan prehipertensi berisiko 4,571 kali untuk mengalami PPHNA dibandingkan dengan yang normotensi. Penelitian oleh Aneni et al $^{11}$ juga memperoleh Odds Ratio yang hampir sama dengan hasil penelitian ini yaitu $\mathrm{OR}=4,5 ; 95 \% \mathrm{CI}=3,7-5,6$.

Pada obesitas sentral terjadi hipertrofi sel-sel adiposit dan perubahan sel-sel pre 
adiposit menjadi sel adiposit. Jaringan adiposa ini akan menyekresi $\mathrm{TNF}-\propto$ dan sitokin proinflamasi lainnya seperti CRP dan IL-6. Sitokin-sitokin pro inflamasi ini menyebabkan terjadinya disfungsi endotel yang kemudian berakibat lanjut peningkatan tekanan darah. ${ }^{12}$

Peningkatan asam lemak bebas merupakan first hit yang mengubah hati normal menjadi steatosis. ${ }^{13}$ Peningkatan asam lemak bebas juga menyebabkan hepatic insulin resistance dengan hasil akhir meningkatkan oksidasi asam lemak bebas menjadi reactive oxygen species (ROS). Stres oksidatif juga mengaktivasi faktor transkripsional NFkB yang selanjutnya meningkatkan produksi sitokin proinflamasi, menghasilkan cedera hepatosit dan apoptosis yang mengarah ke proses steatosis. ${ }^{14,15}$

Pada awal terjadinya steatosis, IL-6 disekresikan dalam jumlah tertentu dan akan membantu proses regenerasi sel-sel hepatosit. Bila steatosis berlanjut terus dan kadar IL-6 terus meningkat maka terjadi resistensi IL-6. Kadar IL-6 yang terus meningkat akan menyebabkan terjadinya peningkatan tekanan darah. ${ }^{16,17}$

\section{SIMPULAN}

Berdasarkan hasil penelitian ini dapat disimpulkan bahwa prehipertensi merupakan salah satu faktor risiko terjadinya perlemakan hati non alkoholik pada obesitas sentral usia dewasa muda. Peningkatan ringan tekanan darah dapat dijadikan prediktor terjadinya perlemakan hati non alkoholik pada obesitas sentral.

\section{DAFTAR PUSTAKA}

1. Lewington S, Clarke R, Qizilbash N, Peto R, Collins R. Age specific relevance of usual blood pressure to vascular mortality. Lancet. 2002;360:1903-13.

2. Chobania AV, Bakris GL, Black HR, Chusman WC, Green LA, Izzo JL, et al. Seventh report of the Joint National Committee on prevention, detection, evaluation, and treatment of high blood pressure. Hypertension. 2003;42(6): 1206-52.

3. Pimenta E, Oparil S. Prehypertension: epide- miology, consequences and treatment. Nat Rev Nephrol. 2010;6:21-30.

4. Skinner AC, Perrin EM, Moss LA, Skelton JA. Cardiometabolic risks and severity of obesity in children and young adults. N Engl J Med. 2015;373(14):1307-17.

5. Wantania F, Panda L, Lefrandt R. Prehypertension is association with the left ventricular hypertrophy in male central obese young adults. GHEART. 2014; 9(1S):PW226.

6. Liszka HA, Mainous AG, King DE, Egam BM. Prehypertension and cardiovascular morbidity. Ann Fam Med. 2005;3:294-9.

7. Italian Association for the Study of the Liver (AISF). AISF position paper on nonalcoholic fatty liver disease (NAFLD): Updates and future directions. Dig Liver Dis. 2017;49(5): 471-83.

8. Greenlund KJ, Croft JB, Mensah GA. Prevalence of heart disease and stroke risk factors in persons with prehypertension in the United States, 19992000. Arch Intern Med. 2004;164: 2113-8.

9. Pletcher M, Bibbins-Domingo K, Lewis C, Wei G, Sidney C, Carr J, et al. Prehypertension during young adulthood and coronary calcium later in life. Ann Intern Med. 2008;149:91-9.

10. Markus M, Strizke J, Lieb W, Mayer B, Luchner A, Doring A, et al. Implication of persistent prehypertension for ageing-related changes in left ventricular geometry and function; the MONICA/KORA Augsburg study. J Hypertens. 2008;26:2040-9.

11. Aneni E, Ali SS, Oni E, Shaharyar S, Blaha M, Martin S, et al. Prehypertension and hypertension are associated with non-alcoholic fatty liver disease independent of traditional cardiovascular disease risk factors. Circulation. 2013;128:A17529.

12. Gavito AL, Bautista D, Suarez J, Badran S, Arco R, Pavón FJ, et al. Chronic IL-6 administration desensitizes IL-6 response in liver, causes hyperleptinemia and aggravates steatosis in diet-induced-obese mice. PloS one. 2016;11(6):e0157956.

13. Demir M, Lang S, Steffen HM. Nonalcoholic fatty liver disease - current 
status and future directions. J Dig Dis. 2015;16(10):541-57.

14. Takaki A, Kawai D, Yamamoto $K$. Multiple hits, including oxidative stress, as pathogenesis and treatment target in non-alcoholic steatohepatitis (NASH). International J Mol Sci. 2013; 14(10):20704-28.

15. Haas JT, Francque S, Staels B. Pathophysiology and mechanisms of non alcoholic fatty liver disease. Annu Rev Physiol. 2016;78:181-205.

16. Schmidt AD, Rose JS. IL-6 pathway in the liver: From physiopathology to therapy. J Hepatol. 2016 Jun;64(6):1403-15.

17. Braunersrither V, Viviani GL, Match F, Montecucco F. Role of cytokines and chemokines in non-alcoholic fatty liver disease. World J Gastroenterol 2012; 18(8):727-35. 